\title{
Introduction: Special Issue on Afro-Americanophilia in Germany
}

\author{
Moritz Ege, Ludwig Maximilian University Munich \\ Andrew Wright Hurley, University of Technology Sydney
}

From a 'provincial' and (hopefully) self-aware European perspective, it is clear that cultural forms or practices that originated among African Americans have, beyond their value to African Americans themselves and people elsewhere, contributed tremendously to life on the European continent. Those contributions include everything from the political imaginaries of the Civil Rights and Black Power movements, through philosophical thought, to literature, film, television, theatre, dance, sports, visual culture and everyday aesthetics. Most prominent, perhaps, have been forms of music - blues and jazz to r'n'b, rap, and hybrid electronic music forms - all of which have 'furnished' European listeners' lives, whatever their so-called race. While deeply embedded racism can run through these processes of cultural flow, transfer, and appropriation, and numerous forms of exploitation are at work, in many cases there is also an ambiguous love for Black diasporic culture, at least according to the appropriating subjects' view of themselves, which manifests itself in admiration, desire, a sense of affinity or connection, and sometimes in fantasies of 'becoming black.' ${ }^{1}$ This issue's papers, which

\footnotetext{
${ }^{1}$ By using terms like 'black' and 'white' we refer to socially dominant categorizations that do not mirror any biologically 'real' essence, but are made meaningful by history and by present forms of ascription, discrimination, and political empowerment movements. Categorizations like 'white' and 'black' are not entirely isomorphic across situations and societal-cultural contexts. We tend to spell the word with a capital letter ('Black') in the context of terminological expressions, of emphatic, affirmative usages and
} 
present case studies of what we will call Afro-Americanophilia, address the forms, ambiguities and politics involved in these cultural processes in 20th-century Germany.

This interest builds on the existing literature about Black diasporic formations, including those in Europe, and on writings on cultural traffic and flow that take place under conditions of inequality. If we take a global view, it is clear that the people, cultures and politics of the Black Atlantic more generally have shaped the experience of modernity and post-modernity in many parts of the world. Paul Gilroy's suggestion that Black Atlantic cultures form a 'counterculture of modernity' (Gilroy 1993: 29) has dominated the research literature on these questions for quite some time. Clearly, people of the Black Atlantic have shaped the world through their labour (for a long time forced/enslaved), ethico-politically (through the influence of social movements and thought that were directed against slavery, colonialism, racism, and sexism), and aesthetically (through arts and cultural production). Furthermore, they have created diasporic modes of belonging and collectivity, that traverse borders and imaginaries, be they national or continental, and simultaneously render the contingent but nonetheless violent nature of such borders more visible. Here, however, following an important yet neglected line of inquiry in works such as Gilroy's, we are interested not so much in the 'negative continent' of the Black Atlantic itself, but in its effect on Europe, and the resulting difficulties of delimiting self and other. Contrary to what old and new forms of racism and nationalism would have us believe, both historically and with regard to 'the contemporary multiculture,' and the results of decades of 'multicultural drift,' Europe is not 'white' (Gilroy 2004: xii; Hall 2013). Or, as Gilroy apodictically put it some years ago, 'the peculiar synonymity of the terms European and white cannot continue' (Gilroy 2004: xii). Of course, the main reason why it cannot continue lies in the political demands for justice and recognition of Europe's diverse populations. Processes of cultural flow and appropriation, however, are another important reason why purity (be it cultural or 'racial') can be no more than a fantasy.

While, on a more descriptive, historiographical level, the fundamental importance of Afro-diasporic presences and influences is relatively well-documented in countries with large Black populations, it is less well known in other countries-like Germany-where 
the actual presence of people of African origin has been relatively small. Yet, here, too, Afro-diasporic influences, or what Harry J. Elam, Jr, and Kennell M. Jackson call global 'black cultural traffic,' have played out in important yet complicated ways (Elam \& Jackson 2005). A body of research literature on this question has started to consolidate, and the goal of this special edition of Portal Journal of Multidisciplinary International Studies is to take a step back, review the literature and its implications and contribute to the historiographic discussion and the attendant wider debate. ${ }^{2}$

A fundamental result of German research to date has been to show that the German interest in Afro-diasporic culture has been far from homogeneous in its forms, functions, politics and positionalities, while, at the same time, some significant patterns of dominance have persisted over long periods of time. 'White' majoritarian Germans, with a variety of attendant convictions and social positions, have brought their desires, preconceptions and the weight of colonial discourses into the equation. Germans of colour, including Black Germans or Afro-Germans, have also engaged in complex ways with things African American. At a basic level, our two joint essays and the individual papers in this special edition seek to plumb that heterogeneity. While we grant most attention to the second half of the twentieth century, our first survey essay sketches the important prehistory. But first some words about terminology.

In order to search for patterns in the heterogeneous German engagement with the black diaspora, we have oriented ourselves by using the term Afro-Americanophilia that Moritz Ege advanced in his 2007 study of West German culture in the late 1960s and early 1970s. In Ege's coinage, the term Afro-Americanophilia denotes a 'cultural theme' of wide-spread enthusiasm for African American culture and politics, which manifested in a surge in 'positive' (often highly sexualized) images of black people in visual culture, high demand for soul music, solidarity activities for the Black Panther Party among student activists, and a wide range of other more or less ephemeral attempts to show closeness to African Americans (see Ege, in this volume). These practices of fashioning white selves by connecting them to signs and experiences coded

\footnotetext{
${ }^{2}$ While this is not the place to comprehensively document how Gilroy's notion of the Black Atlantic (more famous than Robert Farris Thompson's earlier usage) has been received in Germany, it is worthwhile pointing out that the primary vector of reception initially comprised advanced music journalists and cultural critics. A later, more academically oriented milestone was a conference and subsequent publication organized by Paul Gilroy, Fatima El-Tayeb and Tina Campt, and specifically titled 'Der Black Atlantic' (Berlin 2004). Other relevant works include the volume Blackening Europe, edited by Heike Raphael-Hernandez (2004).
} 
as black were especially inflected by the contours of the post-Nazi era, when explicitly racist vocabularies were (largely) taboo in public discourse, and when many-but by no means all-younger Germans searched for identities untainted by the legacy of German fascism. This was also an optimistic time when new African states and the Black Power movement in the USA challenged and redefined the global 'colour line.' From a more critical perspective, however, we can view young Afro-Americanophile Germans of the day as searching for an identification in order to 'align themselves with the victims and avengers of genocide, rather than its perpetrators and accomplices,' and doing so without questioning the implications of their own whiteness, as the drama scholar Katrin Sieg puts it (2002: 13). ${ }^{3}$ In our two joint essays we attend to the ambiguities in post-war Afro-Americanophilia, but we are also interested in the prehistory and afterlife of the high Afro-Americanophilia of the post-war era.

Afro-Americanophilia is a cultural theme that presents itself at different levels and in different intensities. It can denote simple mimesis of 'black' cultural practicesmoments of dancing to 'black' music, singing along, or a passing imaginary identification, as in reading and other forms of cultural reception or consumption. Such moments, ephemeral as they tend to be, do not necessarily have great relevance to the individual, and they certainly do not amount to strong empathy, recognition, or commitment within a collective, but they can contribute to significant overarching cultural themes. For some individuals (and, in some cases, for groups such as youth subcultures), Afro-Americanophilia can also exceed transient moments of mimesis and take the form of a more stable yet somehow ineffable, embodied identification with 'being Black' and with 'Blackness,' that is, with the imaginary essence of the African American experience, whatever that may be understood to mean (Johnson 2003: 4). At different times, various non-black dissidents became disenchanted with their conventional 'white' identities and felt an elective affinity with African diasporic experience. For some protagonists of Afro-Americanophilia, this even became a lifelong process. We can call their type of identification 'enhanced' Afro-Americanophilia. At times Afro-Americanophilia like this can articulate with fantasies and desires of 'becoming black.' 'Becoming black' was famously advanced by the French philosophers Gilles Deleuze and Félix Guattari (1987), who used the term to translate

\footnotetext{
${ }^{3}$ From the beginning, we must stress that German society was not Afro-Americanophile in its entirety; rather, only significant groups within it were.
} 
ambiguous practices of imitation, appropriation, and desire into a fantasy of imaginary or symbolic 'race-change.' The trope of 'becoming black' tended to be employed in verbal discourse with some awareness of its own counterfactual, imaginary character, and the practices that we term Afro-Americanophile could sometimes also be ironic and self-aware. This irony is retained within the term, in the combination of a politically charged 1960s self-designation —'Afro-American'—with a rather formal, antiquated Greek suffix, '-philia.' The neologism is, of course, reminiscent of the term Negrophilia (négrophilie in French), which, as we show in our first joint essay, has been advanced in discussions of 'primitivist' culture of the 1920s, first by its (white) protagonists, then by cultural historians. It is still used by some commentators in order to refer to cases of strong 'white' love for 'Black' culture in the present time. We will discuss Negrophilia in the sense of its 1920s manifestation in our first joint essay, but we will not use the term trans-historically, as the wording seems not suited for that purpose. Instead, in a hopefully more palatable dehistoricization, we apply the neologism Afro-

Americanophilia to phenomena in different historical moments, whether or not the term 'Afro-American' was in use at the time.

When we use the term Afro-Americanophilia in this special issue we mainly have in mind Black cultures in the USA. If, however, the Black Atlantic forms an interconnected entity, this is an arbitrary delimitation. ${ }^{5}$ Nonetheless, German AfroAmericanophilia related largely — but not exclusively — to Black USA, and not, say, to Cuba, Haiti, or Brazil. ${ }^{6}$ While comparisons are difficult to make, it seems safe to say that many 'Afro-Americanophiles' also were much less interested in the cultures, politics, and people from the African continent. The USA was the dominant world power in the $20^{\text {th }}$ century, and we believe there often was a specificity to this 'love' for that reason. This is not to deny that other elements of the Black Atlantic or a less nationally defined sense of 'Blackness' and also 'Africanness' had a part to play in German Afro-Americanophilia, and co-constituted US African American culture, but

\footnotetext{
${ }^{4}$ Echoing the 1970s (predominantly 'white') countercultures' predilection for drama and ecstatic communion, Deleuze and Guattari envisioned new 'blocs of becoming' in which members of minorities and of the majority would communally 'become minor,' that is, leave behind their pre-given, rigid, rationalist, hierarchically positioned subjectivities in a mutual process of transformation and disidentification (Deleuze \& Guattari 1987). See also Wright (2004).

${ }^{5}$ The interconnectedness of the 'creole' zone is a matter that the critic Ernest Borneman was early to contemplate (see Detlef Siegfried's discussion of Borneman in this special edition).

${ }^{6}$ For work on Cuba in the German imaginary, see for example, Hosek (2012); on German engagements with Brazilian and Teuto-Brazilian interculturalities, see Finger, Kathöfer and Larkosh (2015).
} 
we cannot do them justice here. Indeed, we believe that a more precise analysis of those relationships represents a crucial field of on-going and future research. ${ }^{7}$

For the purpose of understanding Afro-Americanophilia, we need to think carefully about temporality. What, exactly, was the relationship between the German love for African American culture in the 1920s and its variant in the 1960s? Were they two instantiations of an 'exoticism' that remained, in its internal structure, more or less identical? Amiri Baraka suggests that African American culture can be seen and heard as a 'changing same' over time, due to a basic 'double consciousness' (W. E. B. du Bois) within the modern world. Does something similar hold true for the ambivalent German love of African American culture? (We will discuss that ambivalence in a moment.) It is for the individual papers in this special edition and other studies to illuminate that question. Our basic methodological sensibility, however, follows Stuart Hall's insights about racism in societies 'structured in dominance,' which stress the specificity of spatiotemporal constellations, even whilst admitting of commonalities between social systems that are structured in a racist way (Hall 1980). Following such an approach, then, we might think of German Afro-Americanophilia as an object that is internally heterogeneous and changes its forms and its meanings, implications and political effects over time. Accordingly, we have sought to analyse specific sociocultural constellations (of desires, of forms of appropriation and solidarity, of subject positions, of agency), without denying that overarching tendencies - especially in power relations - are likely to be relevant.

One obvious way to think about German Afro-Americanophilia is to ponder how to periodize it. We can think of such an endeavour as arriving at a timeline of German 'desire/demand for Black cultural material,' to borrow Kennell Jackson's phrase (2005). Such a timeline must be attuned to three partly countervailing things. It needs to take into account the chronological ruptures of German history; it must take into account the histories of the USA, particularly African American history; but also, conceptually, it needs to be alive to a transnational frame, not just a national or Euro-American one. ${ }^{8}$

\footnotetext{
${ }^{7}$ For example, one phenomenon that we have not been able to analyse in our joint essays, and where the literature is in its infancy, is the German reception of reggae, an Afro-Caribbean form originating in Jamaica, and an Afro-diasporic phenomenon par excellence. It is for future research to determine how its reception and re-contextualization in Germany mirrors or diverges from those of US African American art forms like blues, soul and disco.

${ }^{8}$ Immanuel Wallerstein's writings on 'world systems' are pertinent here (Wallerstein 2011). On the
} 
In our two jointly authored survey essays, we identify the detail and draw out some of the implications of the increasingly diverse research on German Afro-Americanophilia. Our overall approach in these essays is to give an outline of historical phases of AfroAmericanophilia. The underlying aim is to advance a differentiated view of German Afro-Americanophilia that is able to account for the continuities, ruptures and general complexities of global cultural flows and reception. Pulling into focus the Black diaspora's interactions and convergences with German history is important for another reason: it highlights transnational sources of sociocultural change and creativity that are often overlooked in the writing of cultural history. Such a task can destabilize eurocentric narratives and help question the supposed mutual exclusivity of spatiopolitical entities like a nation-state — or a diaspora, for that matter-by showing how such entities overlap and sometimes dissolve.

There is something else that needs to be borne in mind. Cultural life in Germany has been enriched in many ways by Afro-Americanophilia. These contributions can be studied descriptively and analytically, for instance as forms of cultural transfer. ${ }^{9}$ But, as should be clear by now, Afro-Americanophilia is not just a story of contribution, solidarity, and transcultural flow. There has also been contention, misrecognition, struggle, and violence. First of all, unambiguous racism still shapes the reality lived by Black people in Germany and provides a sombre backdrop to stories of AfroAmericanophilia (see e.g. Sow 2008; El-Tayeb 2011). Moreover there can also be a violence intrinsic to '-philia' itself, or to the notion of would-be 'colourblindness., 10 Those Germans who have loved African American cultures were sometimes merely

problems of periodization, see Paul Gilroy's criticism of Habermas, Lyotard, Jameson and others who regard World War II as the significant orientating rupture, globally (1993: 42). For a contrary approach to Europe, using African America as the starting place, see the edited volume, Blackening Europe (RaphaelHernandez 2004).

${ }^{9}$ In such approaches, the analyst often takes a seemingly neutral, unpolitical bird's eye's view, which has been popular in German cultural history. For an overview of models of cultural transfer that has been influential in Germany see e.g. Burke 2000 (originally in English).

${ }^{10}$ As critics like Fatima El-Tayeb note (2011), today many if not most white Germans-including many who have engaged with African American cultures and people - often see themselves as fundamentally non-racial and non-racist: aggressive whiteness is other people's business, as it were. Yet this is despite their (which is to say: our) reliance on an implicitly racialized self-image and a complex regime of border policing that, despite historical and current diversity, maintains the country's dominant white-Germanness, materially and metaphorically, through a repertoire that defines the national body as 'white' and Germans of colour as marginal or not-really-there. El-Tayeb argues that in Europe in general, 'race' figures as an 'unspeakable presence,' which 'makes itself felt from day-to-day interactions to transcontinental political structures, while simultaneously being deemed non-existent within European thought' (El-Tayeb 2011: $\mathrm{xviii)}$. The basic situation is one of a ' peculiar coexistence of, on the one hand, a regime of continentwide recognized visual markers that construct non-whiteness as non-Europeanness with on the other a discourse of colorblindness that claims not to see racialized difference' (El-Tayeb 2011: xxiv). 
'flipping' and positively weighting the negative stereotypes that anti-black German racists applied. Given unequal resources, white Germans' desire for black cultural material has often impelled people of colour to perform to those expectations, accommodate themselves or otherwise negotiate with them. This was certainly the case in the first half of the twentieth century, when many black people found employment as performers under particularly hostile circumstances. Yet many people of colour in Germany today still feel such dynamics when, for instance, stereotypes have an impact upon their employment opportunities (or lack thereof) or on interpersonal encounters. ${ }^{11}$ Given these realities, we need to ensure that accounts of Afro-Americanophilia illuminate not only the functions that these practices fulfilled for (primarily white) actors and their constructions and experiences of their enhanced 'selves,' but also the ways in which individual Black actors accommodate and/or disrupt white desires, or capitalize upon felt empathy and solidarity.

There is an extensive critical literature about the 'white' consumption of racial Otherness (primarily in English, some also in German). The entertainments of blackface minstrelsy and their racial politics and legacies have been debated particularly extensively and controversially. According to Eric Lott's work on North American minstrelsy, Love and Theft (1996), this popular theatrical form was shot through with both revulsion and attraction, and many other things besides. Similar issues arise in the context of 'enhanced' Afro-Americanophilia as well. Critics have hence offered scathing critiques of the racializing exoticism that drove and continues to drive what Norman Mailer (1957) famously called 'the White Negro. ${ }^{12}$ In this context, bell hooks (1992) advanced the influential notion of cultural 'anthropophagy,' stressing the aggressive side of such practices; of incorporation; of the symbolic destruction of a difference that the consumer simultaneously upholds - often in the form of very stereotypical distortions - for the purposes of power and pleasure. From a vantage point of psychoanalysis and cultural theory, Kobena Mercer (2013) and others also enquired

\footnotetext{
${ }^{11}$ For instance, many contributors to the volume Farbe bekennen (Oguntoye, Opitz \& Schultz 1986) - a landmark volume of Black German women's activist writing; see our second joint essay in this special issue — stress that receiving race-based 'compliments' make actual personal encounters very difficult. David Theo Goldberg argues that 'the sometime exoticizing of black bodies and sexuality' in Germany forms the exception to the overall European rule of 'casualness about interracial social intercourse' (2009: 185). For an ethnographic account of this exoticization, seen from different perspectives, see Partridge (2012).

${ }^{12}$ On German iterations of the 'White Negro' in West Germany in the 1960s, see Siegfried (2010); James Baldwin's contemporaneous critique is discussed in the essays by Ege and Hurley below.
} 
into the ways in which racial fetishization can be at play. Such approaches add depth to more materialist arguments like those of Amiri Baraka (1995) and Perry A. Hall (1997) that highlight the appropriation (or rather expropriation) of Black cultural production for white profit. In combination, these debates have fundamentally changed the ways that processes of projection and appropriation are discussed in the USA and elsewhere. However, despite such critical interventions overseas and although such an analysis has been advocated outside the mainstream German media by antiracist activists and scholars for some time (see references below), such ideas are not yet widespread in Germany. Indeed, to people from countries with a longer tradition of Black activism, it often comes as a shock to see how white Germans have felt at liberty to put on blackface, literally and figuratively. The shock is compounded by how socially accepted such practices are, and by how aggressively many Germans reject any criticism of those practices. ${ }^{13}$ Critical voices, particularly those of Black German intellectuals, have for a long time remained on the margins.

Having said that, we do need to recognise that the status quo is also being challenged. Questions of 'race' and its relevance in Europe and in Germany, in particular, are being posed more explicitly, in a more sustained way, and by a more diverse group of people, though the strength of the concomitant backlash is hard to measure. In academia, numerous texts on Afro-Germans, on African Americans and Germany, and on Blacks in Germany have been published recently, as we will discuss their implications for a history of Afro-Americanophilia further in our two joint essays. The shifting academic focus is entangled with broader transformations in the social world too. It reflects, variously, the rising relevance of concepts of race, racism and ethnicity in a more diverse Germany, ${ }^{14}$ the transnational trend in historiography, and, especially, the growth and increasing political consciousness of Black Germans. These are crossed with changes in the media that can allow critical voices to cut through (Sieg 2015). European

\footnotetext{
${ }^{13}$ This is a point made by Katrin Sieg, in the introduction to her seminal study of 'ethnic drag' practices in Germany. She notes, for example, that whereas French audiences found a 1988 blackface performance 'utterly offensive,' Germans regarded such practices as 'utterly unremarkable'; indeed they have acquired 'normative status on the West German stage' (Sieg 2002: 2). On recent responses to contemporary blackfacing in Germany, compare Thurn (2014) and Sieg (2015).

${ }^{14}$ In Germany, the demographic descriptor 'background of migration' is commonly used. It is unclear and problematic - for example, it includes Germans born in Germany whose parents came from elsewhere. In some ways, however, it seems an indispensable category, especially given that 'race' was a taboo subject for surveys. The overall percentage of people with such a background is about 20 percent. In many urban schools, students whose parents speak a language other than German are in a numeric majority. For statistics, see 'Migration, Integration' (2015).
} 
Union policies relating to diversity and anti-discrimination are requiring changes in local administration and everyday life. Critical studies by Susan Arndt (2001), Maureen Maisha Eggers et al. (2005), Kien Nghi Ha et al. (2007), Grada Kilomba (2008), Noah Sow (2008), Susan Arndt and Nadja Ofuatey-Alazar (2011) and others foreground the knowledge of people of colour about racism and question the privileges of being 'white' and discursively 'unmarked.' Works such as Fatima El-Tayeb's Europe's Others: Queering Ethnicity in Postnational Europe (2011) also question how Black European cultural politics relate to broader European minority discourses.

Given these different intellectual traditions and political standpoints, our focus on AfroAmericanophilia is intended to contribute to an analysis of sociocultural life that critically reflects cultural and social structurings through race and highlights relations rather than substances or essences. We intentionally do not pose a transhistorical question about Afro-Americanophilia's effects. Instead, in different case studies and situations, the authors decipher a contentious network of distributed agency that sometimes remains a 'white' monologue, and sometimes creates 'lines of flight' for different subjects and actors, to use Deleuze and Guattari's vocabulary (1987). Examining these networks and lines of flight adds to our understanding of the continuing relevance of 'race' in Germany, and provides insights into the workings of racialized sociocultural formations that might otherwise go unnoticed. After all, if racism is a problem that white people cause, then understanding it - in order to overcome it - requires us to examine the affective undercurrents of whiteness. The case studies in this special issue provide particularly relevant material on which to do so.

\section{The individual papers in this issue}

In the two jointly authored survey essays included in this special issue, we advance a two-part periodization of twentieth century German Afro-Americanophilia. The first essay examines the 'pre-history' of Afro-Americanophilia, beginning with the reception in German-speaking lands of African people, ideas and cultures prior to the $19^{\text {th }}$ century. We then look at the German reception of such things as the antebellum US novel by Harriet Beecher Stowe, Uncle Tom's Cabin, before moving through the German colonial, the Weimar, the National Socialist and the postwar eras, when cultural forms such as minstrelsy, ragtime, cakewalk, jazz and other Afro-diasporic musical forms were received in Germany. The essay also examines the ways in which the lives of 
Afro-Germans during these eras are being painstakingly reconstructed by historians. The second essay tracks the contours and manifestations of Afro-Americanophilia in the counter-culture era and beyond that era. The authors attend to Afro-Americanophile aspects of the new social movements in Germany, including second-wave feminism and Afro-German activism, and contemplate further 'hotspots' in the reception of Afrodiasporic cultural forms, including disco, hiphop and techno. The authors finally return to the question of what continuities an attempt to periodize Afro-Americanophilia might obscure.

The historian Detlef Siegfried turns his attention to the crucial figure of Ernest (Ernst) Borneman(n), who emigrated from Germany in the 1930s and, in his own way, re-traced some of the legs of the Black Atlantic, spending time in the UK and in North America prior to returning to German-speaking lands in the 1960s. In a remarkably broad career that spanned literary writing, film-making, ethnomusicology and sexology, Borneman also pioneered jazz scholarship, applying what he referred to as an anthropological perspective to the art form. He benefited from personal contact with Afro-Caribbean expatriates resident in London, and later engaged in an important public dispute with Amiri Baraka over Black cultural nationalism and jazz.

Cultural historian Andrew Hurley examines the Afro-Americanophile changes evident in the career of the West German jazz writer, producer and broadcaster, Joachim Ernst Berendt. He contemplates how Berendt earnestly deployed Afro-Americanophilia in the postwar era in a moralistic attempt to render German culture less chauvinist. He then examines how Berendt's Afro-Americanophilia broke down after being confronted by militant Black nationalism in the late 1960s, and how Berendt's -philic energies mutated into what might be called polyphilia.

In his contribution, Moritz Ege turns special attention to both the wide-spread commoditization of Afro-Americanophilia in the late 1960s and early 1970s in West Germany, and the counter-cultural manifestations of the Afro-Americanophile cultural theme during the same era, which included the activities of a small movement that named itself the 'Berlin Blues.' As the article shows, the 'racial' undertones of ideas of sexual liberation and cultural revolution were important in connecting both realms and, more generally, in forming subjectivities of the 1968 generation.

Finally, hip-hop scholar Leo Schmieding analyses the different ways in which East- 
Germans engaged with hip-hop culture during the final decade of the German

Democratic Republic. He considers interpretations of US hip-hop as the 'second culture' of an oppressed working class, and he also examines how grass-roots East German rappers began to make the idiom their own. In this context, Schmieding contemplates the double role of the DT64 broadcaster Lutz Schramm, who kept the functionaries happy with his verbal mediation of the hip-hop genre, but also provided the scene with the music and arcane knowledge they hungered for, as well as a platform where their own efforts could be publicized.

These case studies give new insights into important aspects of Afro-Americanophilia in 20 th century Germany and into some of its protagonists. We acknowledge that the case studies' primary preoccupation is with (white) men, who with their constructions and deconstructions of whiteness and masculinity undoubtedly form a core German AfroAmericanophile group, and we also recognise that the articles were written from similar positionalities. We planned a larger special edition that would have included a wider and more diverse array of topics and writers, but unfortunately that did not come to pass. We proceeded with the scaled back edition in the belief that it adds to the already wideranging and multifaceted literature, but fully aware that there is much more to tell. Readers wishing to investigate those other areas are directed to the literature that we discuss in this introduction, and especially in Ege's and Hurley's two jointly authored survey essays.

\section{Acknowledgements}

As guest editors of this special edition, we would like to thank all the contributors, as well as the peer reviewers, and the journal's editor, Paul Allatson.

\section{Reference List}

Arndt, S. (ed.) 2001, AfrikaBilder: Studien zu Rassismus in Deutschland [Images of Africa: Studies on Racism in Germany]. Unrast Verlag, Münster.

Arndt, S. \& Ofuatey-Alazar, N. (eds) 2011, Wie Rassismus aus Woertern spricht [How Racist Words Speak]. Unrast Verlag, Münster.

Baraka, A. [LeRoi Jones] 1995 [1963], Blues People: Negro Music in White America. Payback, Edinburgh.

Burke, P. 2000, Kultureller Austausch [Cultural Exchange]. Suhrkamp, Frankfurt am Main.

Deleuze, G. \& Guattari, F. 1987, A Thousand Plateaux: Capitalism and Schizophrenia, (trans.) B. Massumi. University of Minnesota Press, Minneapolis.

Ege, M. 2007, Schwarz Werden: 'Afroamerikanophilie' in den 1960er und 1970er Jahren [Becoming Black: 'Afroamericanophilia' in the 1960s and 1970s]. Transcript Verlag, Bielefeld. doi: http://dx.doi.org/10.14361/9783839405970

Eggers, M. M. et al., (eds) 2005, Mythen, Masken und Subjekte: Kritische Weissseinsforschung in 
Deutschland [Myths, Masks and Subjects: Critical Whiteness Studies in Germany]. Unrast Verlag, Münster.

Elam, H. J., Jr., \& Jackson, K. (eds) 2005, Black Cultural Traffic: Crossroads in Global Performance and Popular Culture. University of Michigan Press, Ann Arbor.

El-Tayeb, F. 2011, European Others: Queering Ethnicity in Postnational Europe. University of Minnesota Press, Minneapolis.

Finger, A., Kathöfer, G. \& Larkosh, C. (eds) 2015, Kulturconfusao: On German-Brazilian Interculturalities. Walter De Gruyter, Berlin \& Boston.

Gilroy, P. 1993, The Black Atlantic: Modernity and Double Consciousness. Harvard University Press, Cambridge, MA.

Gilroy, P. 2004, 'Foreword: Migrancy, Culture, and a New Map of Europe,' in Blackening Europe: The African American Presence, (ed.) H. Raphael-Hernandez. Routledge, London \& New York: xixxii.

Goldberg, D. T. 2009, The Threat of Race: Reflections of Racial Neoliberalism. Wiley-Blackwell, Malden, MA.

Ha, K. N. et al., (eds) 2007, Postkoloniale Perspektiven von People of Color auf Rassismus, Kulturpolitik und Widerstand in Deutschland [Postcolonial Perspectives of People of Colour on Racism, Cultural Politics and Resistance in Germany]. Unrast Verlag, Münster.

Hall, P. A. 1997, 'African-American Music: Dynamics of Appropriation and Innovation,' in Borrowed Power: Essays on Cultural Appropriation, (eds) B. H. Ziff \& P. V. Rao. New Brunswick: Rutgers University Press, Brunswick: 31-51.

Hall, S. 1980, 'Race, Articulation and Societies Structured in Dominance,' in Sociological Theories: Race and Colonialism. UNESCO Publishing, Paris: 305-345.

Hall, S. 1980, 'The Spectacle of the "Other,"' in Representation: Cultural Representations and Signifying Practices, (eds) S. Hall et al. $4^{\text {th }}$ edition. Sage \& Open University Press, London \& Milford Keynes: 215-287.

hooks, b. 1992, 'Eating the Other: Desire and Resistance,' in Black Looks: Race and Representation. South End Press, Boston: 21-39.

Hosek, J.R. 2012, Sun, Sex and Socialism: Cuba in the German Imaginary. University of Toronto Press, Toronto.

Kilomba, G. 2008, Plantation Memories: Episodes of Everyday Racism. Unrast Verlag, Münster.

Lauré al-Samarai, N. 2004, 'Unwegsame Erinnerungen: Auto/biographische Zeugnisse von Schwarzen Deutschen aus der BRD und der DDR' [Impassable Memories: Auto/biographical Testimonies of Black Germans from the FRG and the GDR], in AfrikanerInnen in Deutschland und schwarze Deutsche. Geschichte und Gegenwart [Africans in Germany and Black Germans: Past and Present], (eds) M. Bechhaus-Gerst \& R. Klein-Arendt. Lit Verlag, Münster: 197-210.

Mailer, N. 1957, The White Negro. City Lights Books, San Francisco.

Mazón, P. \& Steingröver, R. (eds) 2005, Not So Plain as Black or White: Afro-German Culture and History, 1890-2000. Rochester University Press, Rochester.

Mercer, K. 2013, 'Reading Racial Fetishism,' in Representation: Cultural Representations and Signifying Practices, (eds) S. Hall et al. $4^{\text {th }}$ edition. Sage \& Open University Press, London \& Milford Keynes: 280-287.

Oguntoye, K., Opitz [Ayim], M., \& Schultz, D. (eds) 1986, Farbe bekennen: Afro-deutsche Frauen auf den Spuren ihrer Geschichte [Showing [their] Colours: Afro-German Women in Search of Their History]. Orlanda, Berlin.

Oguntoye, K., Opitz [Ayim], M., \& Schultz, D. (eds) 1991, Showing Our Colors: Afrogerman Women Speak Out. University of Massachussetts Press, Amherst.

Partridge, D. 2012, Hypersexuality and Headscarves: Race, Sex, and Citizenship in the New Germany. Indiana University Press, Bloomington.

Raphael-Hernandez, H. (ed.) 2004, Blackening Europe: The African American Presence. Routledge, London \& New York.

Sieg, K. 2002, Drag: Performing Race, Nation, Sexuality in West Germany. University of Michigan Press, Ann Arbor.

Sieg, K. 2015, 'Race, Guilt and Innocence: Facing Blackfacing in Contemporary German Theater.' German Studies Review, vol. 38, no. 1: 117-134. doi: http://dx.doi.org/10.1353/gsr.2015.0007

Siegfried, D. 2010, 'White Negroes: The Fascination of the Authentic in the West German CounterCulture of the 1960s,' in Changing the World, Changing Oneself: Political Protest and Collective Identities in West Germany and the U.S. in the 1960s and 1970s, (ed.) B. Davis. Berghahn, New York \& Oxford: 191-215. 
Sow, N. 2008, Deutschland Schwarz Weiss: Der alltaegliche Rassismus [Germany Black and White: Everyday Racism]. Bertelsmann, Munich.

Thompson, R. F. 1983. Flash of the Spirit: African and Afro-American Art and Philosophy. Vintage, New York.

Thurn, N. 2014, 'Dieses Stück Genets wird jede deutsche Bühne überfordern. Zur Rezeption von Jean Genets "Les Nègres" in Deutschland.' [This Piece by Genet Would Overtax Every German Theatre: On the Reception of Jean Genet's Les Negres in Germany], Jean Genet und Deutschland [Jean Genet and Germany], (eds) M. N. Lorenz \& O. Lubrich . Merlin, Gifkendorf: 277-300.

'Migration, Integration' 2015, Statistisches Bundesamt. Online, available: https://www.destatis.de/DE/ZahlenFakten/GesellschaftStaat/Bevoelkerung/MigrationIntegration/ MigrationIntegration.html [Accessed 20 April 2015].

Wallerstein, I. 2011, Modern World-System II: Mercantilism and the Consolidation of the European World-Economy, 1600-1750. 2nd edition. University of California Press, Berkeley.

Wright, M. 2004, Becoming Black: Creating Identity in the African Diaspora. Duke University Press, Durham, NC. 